This chapter is forthcoming in the Routledge Handbook to the Philosophy of Relativism, edited by M. Kusch, Routledge (London, New York).

\title{
Relativism in the Context of National Socialism
}

Johannes Steizinger

McMaster University

\section{Abstract}

The aim of this chapter is to clarify the use and meaning of the concept of relativism in the context of National Socialism (NS). Section 1 examines the critical reproach that NS is a form of relativism. I analyze and criticize the common core of this widespread argument which has dominated discussions about the topic up to the present. Section 2 sketches the general debates on relativism before and during NS. I show that fascist thought could be associated with both relativism and anti-relativism. In contrast to the received view, I argue that Nazi intellectuals regarded relativism as problem, and presented NS as the overcoming of relativism. Subsequently I turn to two major philosophers who connected their philosophy with NS. Section 3 investigates Bruno Bauch's (1887-1942) nationalist philosophy. I show that he linked his concept of the nation with an objectivist value theory intended to oppose all kinds of relativism. Section 4 turns to Erich Rothacker's (1888-1965) cultural anthropology. I argue that the revision of his philosophical views in the 1930s was accompanied by a political turn towards NS and a withdrawal from relativism. The brief conclusion (Section 5) summarizes the findings of the chapter. I conclude that, in the context of NS, relativism is mostly used in a pejorative sense. 
Relativism and NS are often associated with each other in the philosophical literature. This association is used as a critical argument against both. The weakest form of this argument runs as follows:

Relativism involves the idea that there are many radically different, yet equally valid, epistemic or moral systems. The "equal validity" idea commits the relativist to a strong form of tolerance even of morally and epistemically highly problematic systems of thought. Hence, relativism does not provide us with the normative resources to criticize irrational views such as Nazi racism. We need a normative universalism to confront racist ideologies (Böhler 1988, Tugendhat 2009, Kellerwessel 2014).

The different versions of the above anti-relativist argument share a common core: Their advocates embed their identification of NS with relativism in a broader claim about the nature of philosophy. They argue that philosophy has to be based on reason and that this in turn commits one to absolute truth. Moreover, these authors defend the possibility of objective knowledge about reality and believe in a universal foundation of morality.

The systematic criticism of relativism in the context of NS, is often supported by the historical argument that the relativism of post-Hegelian philosophy paralyzed the moral consciousness of German intellectuals during Weimar Republic. Their inability to mobilize universal moral principles is regarded as a reason for the rise of NS (Apel 1988). This historical argument can even take a stronger form. Some authors argue that the relativism of post-Hegelian philosophy is a prerequisite of Nazi ideology. Here Nazi ideology is classified as a radical kind of relativism that emerges from the general path of German philosophy after Hegel (Böhler 1988; Wolin 2004; Kellerwessel 2014).

The identification of NS with relativism has a long history and is still popular today. The most influential account stems from Georg Lukács (1885-1971) in his polemical treatise Die Zerstörung der Vernunft (The Destruction of Reason, 1954). 
The Neo-scholastic Josef de Vries (1898-1989) confronted Nazi philosophers with the charge of relativism already in the 1930s (de Vries 1935a; 1935b). Many of the critics, past and present, accuse especially historicism and Lebensphilosophie (philosophy of life) of having advocated a "dangerous" relativization of truth, knowledge, and values. On this view, the "relativistic nineteenth century" created a philosophical framework that enabled the flourishing of irrational beliefs, arbitrary maxims, and nihilistic attitudes. Ideologies such as NS are regarded as the ultimate step in the "destruction of reason" (Lukács 1954; see also de Vries 1935a; 1935b; Lieber 1966; Apel 1988; Böhler 1988; Wolin 2004).

Recent accounts highlight the destruction of moral rationality by the alleged relativism of Nazi racism. They read Nazi ideology as a biological determinism that attributes mutually exclusive sets of values to the assumed races. The particular values of a race are chosen arbitrarily and are understood only instrumentally: they serve the survival and flourishing of the respective race. The alleged racial hierarchy has no normative foundation and is thus completely arbitrary too. This "extreme relativism" of NS is defined as the opposite to moral rationality and is considered as an attack on philosophy itself (Böhler 1988; Tugendhat 2009; Kellerwessel 2014). Earlier accounts emphasize the opposition of NS to rationality in general. Lukács characterizes Nazi ideology as a modern myth that is nothing more than demagogic and nihilistic propaganda designed to deceive the population. Here NS is portrayed as the consequence of the decay of philosophy that was caused by relativism. Following Lukács, Hans-Joachim Lieber (1923-2012) explicitly defines NS as the "end of philosophy" (Lieber 1966, 93). ${ }^{\text {. }}$

There are several reasons why the argument equating NS with relativism is problematic. First, it rests on strong background assumptions about the nature of philosophy and morality. Most presentations of the argument simply take absolute standards for granted.

Second, "relativism" is used exclusively in a pejorative sense. And this pejorative use of the concept of relativism makes the historical argument problematic. The 
historical accounts are uncharitable and not based on the detailed study of existing sources. Historicism and Lebensphilosophie are used as mere whipping boys.ii

Third, the argument equating NS with relativism rests on a poor understanding of Nazi ideology. Recent historical research shows that Nazi ideology can neither be reduced to deceitful propaganda nor to simple biologism. The mere fact that many professional philosophers contributed to Nazi ideology should already make us doubt the equation of National Socialism with "the end of philosophy."

Fourth, and most importantly, most critical anti-relativists do not consider the actual debate about relativism in the context of NS. Since Nazi philosophers were accused of being relativists by their contemporaries such as de Vries (1935a; 1935b), they engaged seriously with the problem of relativism. The actual contributions of Nazi philosophers to this debate reveal their self-understanding and are therefore an important source for defining the relation of NS to relativism. The critical analysis of this engagement also shows the meaning and use of the concept of relativism in the historical context. In the next section, I examine this historical context.

\section{The Historical Debate: NS versus Relativism}

Nazi intellectuals were confronted with philosophical problems such as relativism because of the comprehensive character of their political claims. NS considered itself as a political revolution that realizes a new image of the human. Recent historical research confirms the self-understanding and contemporary perception of NS as a weltanschauliche Bewegung (ideological movement; see Kroll 1998; Raphael 2014).

The Nazis adopted the concept Weltanschauung (worldview) in order to highlight the comprehensive character of their movement. Because of its thoroughgoing political character, the Nazi Weltanschauung can be characterized as an ideology. 
Nazi ideology has to be seen as a set of basic beliefs and convictions which left much scope for interpretation. Although key concepts like race had to be accepted as guidelines of thinking and acting, different interpretations of such ideological core elements coexisted and competed even in the inner circle of Nazi leadership. In short, there was no unified and mandatory ideological system of NS. Nevertheless, Nazi ideology was not a chimera. The "combination of fluidity and flexibility with a set of convictions and core arguments" (Raphael 2014, 74) shows, instead, that a political ideology works best as controlled plurality. Take the example of the concept of race: once you had accepted its key role for understanding whatever phenomenon interested you, you could still engage in heated debates on its meaning and significance. The range of views developed in the writings of NS leaders reached from bluntly biological conceptions (e.g. Darré [1902-1946]) to metaphysical interpretations of race (e.g. Rosenberg [18931946)). Such obvious tensions were never removed and created the impression that NS was always in need of further explication.

Philosophers in particular took up the task of elaborating, justifying, and explaining what NS truly is. Many German philosophers put their philosophy into political service. The gesture of general agreement with the political change and the willingness to work in the direction of the leader (dem Führer entgegenarbeiten) were even more widespread.iii

NS and philosophy were linked by the concept of Weltanschauung. This vague concept generally connected philosophy and politics in the early twentieth century. The concept referred to comprehensive theories about the world that were meant to guide human actions. There was no sharp distinction between philosophy and Weltanschauung.

Weltanschauungsphilosophie (philosophy of worldviews) became the dominant force in German-speaking philosophy during Weimar Republic. This is demonstrated by the influence of Oswald Spengler's (1880-1936) Untergang des Abendlandes (Decline of the West; 1918/1922) on public discourse, on political 
debates, and in academic philosophy (see e.g. Kusch 1995, 227 f.) Spengler connected a general theory of culture with a critical diagnosis of its current state. He claimed that Western culture had reached the final stage of cultural life. This state of decline could only be managed by the individual authority of a dictator. Spengler embraced the political idea of Caesarism and regarded Mussolini's fascism as its modern realization (see Felken 2006, 1256 f.). This political conservatism was accompanied by a philosophical commitment to relativism. ${ }^{\text {iv }}$ Spengler believed that all forms of human expression were determined by their historical context (Spengler 2006, VII, $31 \mathrm{f}$.). Human history consisted of the life of cultures. Spengler defined cultures as distinct organisms with individual, incommensurable characteristics. He thus combined historicism with cultural relativism.

Other authors referred to the legacy of historicism by taking up Wilhelm Dilthey's theory of worldviews within academic philosophy. ${ }^{v}$ Erich Rothacker published a new Einleitung in die Geisteswissenschaften (Introduction to the Human Sciences; 1920) that was followed by his Logik und Systematik der Geisteswissenschaften (Logic and System of the Human Sciences; 1926). In this period, Rothacker claimed that the methodological debates about scientific principles reflected fundamental "struggles of life" $(1926,112)$. He argued that these debates could be reduced to the fundamental differences of metaphysical Weltanschauungen. Rothacker regarded Weltanschauungen as rooted in decisions about life. They expressed practical demands and ethical postulates that could not be reconciled $(137,139)$. Rothacker highlighted the troubling consequences of his understanding of science. On his view, there was no science without presuppositions (voraussetzungslose Wissenschaft). Such positions were often accused of being relativistic.

In his treatise from 1926, Rothacker explicitly addressed said problem of relativism. He distinguished between a positive and a negative kind of relativism. Rothacker suggested that "negative relativism" was a kind of skepticism that had to be rejected because of its "decomposing" effects (1926, 147 f.). "Positive relativism", on the other hand, simply acknowledged that humans had to choose 
among different possibilities of life. The choice between a plurality of values was guided by practical interests. Rothacker embraced this pragmatic principle and defined himself as a positive relativist. He regarded this position as a legacy of historicism. He affirmed the historicist's emphasis on historical particularity also in the realm of politics. Rothacker praised cultural particularism and concluded in the last section of his systematic treatise: "Only on this ground, we philosophers are entitled to love our country" (171). Again, philosophical relativism was connected with political conservativism. ${ }^{\text {vi }}$

Nazi ideology thus emerged in the context of a political discourse that associated some of its key convictions with relativism. This might lead one to expect that Nazi intellectuals referred to relativism in a positive way. This expectation is, however, not supported by historical evidence. The intellectual discourses of the Nazi era reveal a commitment to anti-relativism: For instance, the popular Meyers Dictionary of 1942 defined relativism as an attitude that represents the modern liberal-individualistic perplexity and lack of principles. "Jews" allegedly belonged here because of their disposition and intention to "decompose" society (Meyers Lexikon 1942: 290). Nazi scientists also rejected Einstein's theory of relativity because of its alleged "decomposing" impact on society (see Herbert 2001, 12-14, 213; Danneberg 2013, 74 ff.). Nazi accounts of contemporary philosophy defined relativism as a dangerous consequence of the modern spirit for which intellectual tendencies such as individualism, liberalism, historicism, and pragmatism were responsible. vii They often referred to German-Jewish philosophers such as Georg Simmel as prime examples of relativistic attitudes. ${ }^{\text {viii }}$ In 1936, the historicalphilosophical class of the Prussian Academy of Sciences announced a prize question on the topic: "the inner reasons of philosophical relativism and the possibility of its overcoming." The prize question presented relativism as philosophical problem that had to be overcome. ${ }^{\text {ix }}$

This overview shows that the philosophical, scientific, and public debates during NS presented relativism as a problem. Moreover, anti-relativism featured prominently in antisemitic propaganda. It is thus not surprising that Nazi 
intellectuals presented their worldview as the overcoming of relativism. The Nazi ideologue Alfred Rosenberg characterized the idea of the "relativity of the universe" as an "illness of our time" that was overcome by the "organic truth of NS" $(1938,694)$. Nazi philosophers such as Alfred Baeumler or Ernst Krieck were convinced that their position overcame the opposition between absolutism and relativism. They developed argumentative strategies to present NS as a third way in philosophy. ${ }^{x}$

These anti-relativistic convictions of Nazi intellectuals expose the weakness of the received view of NS as relativism. Nazi ideology did not follow the relativistic strand of political conservativism, but adopted an anti-relativistic stance that was widespread in German-speaking philosophy (see, e.g., Kinzel, this volume.)

This understanding of relativism shaped an important political debate during Weimar Republic. Anti-relativism was a key motivation for Carl Schmitt's (18881985) political conservativism. Schmitt claimed that liberal democracy was rooted in the relativism of modern thinking. He regarded the liberal politics of tolerance as a relativistic principle and identified this constitution with the decline of political authority. For Schmitt, Hans Kelsen (1881-1973) represented the relativistic mind-set of political liberalism (Schmitt 2009, 47-55; see also Schmitt 1931; $1916,59,65,67-70) .{ }^{x i}$ Schmitt's anti-relativism was explicitly connected with an antisemitic sentiment. Schmitt saw his controversy with Kelsen as a "struggle against the Jewish spirit", his "true enemy" (see Gross 2016).

In what follows, I want to take a closer look at two philosophical approaches to relativism during NS. Bruno Bauch and Rothacker connected their philosophies with NS and engaged with the problem of relativism. Moreover, their philosophical endeavors represent the two main tendencies of German-speaking philosophy before and during NS. Hans Sluga (1993) has convincingly shown that the diverse landscape of early twentieth-century philosophy was divided into two general camps: The "philosophical conservatives", on the one hand, saw their philosophizing as the recovery of a great past. The neo-Kantian Bauch was one of 
the most influential proponents of a distinctively "German" philosophy that was grounded in the idealist tradition of Kant, Fichte, and Hegel. The "philosophical radicals", on the other hand, demanded a radical new beginning and developed varying proposals for this task. Rothacker reinvented philosophy multiple times during his philosophical career and became a leading proponent of the "philosophical radicals" in the 1930s.

\section{Bruno Bauch's Objectivist Nationalism}

The neo-Kantian Bauch was an influential figure in early twentieth-century philosophy. His infamous lecture Vom Begriff der Nation (On the Concept of the Nation)--given in 1916 and published as an article in 1917--caused a scandal that divided the philosophical community. The publication of Bauch's nationalist and antisemitic views in Kant-Studien (Kant Studies), the journal of the KantGesellschaft (Kant-Society), prompted protests of German-Jewish philosophers in particular. In response Bauch founded the Deutsche Philosophische Gesellschaft (DGP; German Philosophical Society) as an alternative to the Kant Society. In one of its first programmatic statements, the society announced that it aimed to cultivate, deepen, and preserve the "German character" in philosophy. ${ }^{\text {ii }}$ This program attracted all kinds of conservative, nationalist, and racist philosophers.

Bauch believed that humanity consisted of distinct nations. He claimed that fostering nationalist attitudes was a prerequisite for the flourishing of humanity (1917, 160-162; see also 1935, 228). Bauch thus emphasized the general character of his nationalist views. In his article from 1917, he developed a völkisch particularism. He construed nations as distinct and mutually exclusive entities. The individual character of a nation could not be understood by members of another nation. Bauch explicitly denied "Jews" the ability to understand the cultural achievements of Germans.

Bauch claimed that his concept of the nation followed the German tradition, especially Fichte (139 f., 149, 150-153). He held that nations were the synthesis of 
a natural fact (natürliche Gegebenheit) and a cultural fact (kultürliche Gegebenheit). The nature of a nation consisted of biological, spiritual, and linguistic components. Bauch believed that human communities were rooted in biological groups. This biological link shaped the physical appearance of nations. He insisted that there were physical types that could be easily distinguished by their skin color, their face shape, their body type, and their skull shape $(141,144)$. He also claimed that the members of a nation shared a way of thinking, feeling, willing, and acting. This spiritual link constituted the distinct soul of nation (141144). Finally, the specific character of a nation was expressed in their common language (157 f.).

The cultural unity of a nation was realized in history. Bauch claimed that nations developed self-consciousness through their history. They became aware of their historical destiny and expressed their national consciousness in cultural goods. From the perspective of culture, nationhood was thus a task that had to be fulfilled. Construed as an end, nationhood participated in the transcendent realm of values. Hence, nations possessed an objective meaning through their cultural existence (144, 148 f., 156-58).

The particularist foundation of Bauch's völkisch nationalism clearly had a relativistic tendency. Bauch distinguished a plurality of distinct nations and postulated an incommensurability between them. This view could prepare the ground for cultural relativism. Bauch, however, believed that his objectivist understanding of the cultural aspect of nations blocked the paths towards relativism. This conviction becomes apparent in a lecture from October 1933 about Wert und Zweck (Value and Purpose) that was published in the 1934/35. xiii Bauch gave the lecture at the twelfth annual conference of the DGP. The conference was an occasion for the DPG to pledge its allegiance to the Nazi regime-Hitler indeed sent his greetings. ${ }^{\text {iv }}$

In his article from 1934/35, Bauch fiercely attacked critics of a transcendent realm of values. He characterized the deniers of the independence of objective values as 
subjectivists. On Bauch's view, all relationist concepts of values fell prey to the charge of subjectivism. He identified subjectivism with relativism. Bauch regarded pragmatism, utilitarianism, and materialism as modern kinds of philosophical relativism. He also referred to Plato's devastating critique of Protagoras and agreed with its dehumanizing images: Bauch claimed that the denial of the objectivity of values revealed the personal inferiority of the relativists. Their subjectivism degraded them to the rank of "baboons", "tadpoles", or "pigs" with whom a discussion was superfluous (Bauch 1934/35, 43 f. 49 f.).

Bauch connected his fierce polemic against relativism with a critique of his time. He praised NS as the political overcoming of the "pragmatist-materialist demon" (pragmatisch-materialistische Ungeist; 52) that haunted modernity. Intellectual developments such as individualism, atheism, or liberalism were characterized as "decomposing" the value foundation of society. The antisemitic character of Bauch's critique of relativism was obvious in his discussion of science. Bauch held that pursuing truth was the sole task of all scientific endeavors. At the same time, he accused "Einstein, Freud, and co." of trying to turn science into a tool for personal interests (53). He contrasted the alleged egoism of "Jewish" scientists with the German attitude to science: Germans were capable of doing science for its own sake. They acknowledged the unconditional value of truth. (52). ${ }^{x v}$

\section{Ernst Rothacker's Realist Perspectivism}

Rothacker believed that one had to understand humanity through its cultural achievements. His thesis from 1912 takes Lamprecht's historiography and Wundt's Völkerpsychologie (ethnic psychology) as starting points for a biologistic concept of culture. After WWI, Rothacker's philosophical interests changed significantly. He turned to Dilthey's theory of worldviews and developed a historicist understanding of humanity. In the 1920s--the middle period of his work-Rothacker committed to "positive relativism" and explicitly took sides in politics. From 1919 to 1928, he was member of the Deutsche Volkspartei (German People's Party) which combined a skeptical attitude towards Weimar Republic with a 
nationalist and business-friendly agenda. Around 1930, Rothacker began to develop his cultural anthropology and published two major treatises that set out his new views: Geschichtsphilosophie (Philosophy of History) in 1934 and Probleme der Kulturanthropologie (Issues of Cultural Anthropology) in 1942 (republished in 1948). The second fundamental revision of his philosophical thought was accompanied by a political turn to NS.

From the beginning, Rothacker associated the revision of his philosophical position with the rise of NS. His Geschichtsphilosophie from 1934 started with the claim that the upcoming "folkish consciousness" (volkstümliche Bewußtsein) constituted the beginning of a new epoch. Rothacker stated that his philosophy revealed the anthropological foundation of this historical transformation. Moreover, he concluded his Geschichtsphilosophie with an explicit political statement. The chapter Im dritten Reich argued that his philosophy belonged to the new world order by showing its conformity with key features of Nazi ideology. ${ }^{x v i}$

Völkisch particularism was also at the core of Rothacker's cultural anthropology. Human history was characterized by the struggle of particular communities for the realization of their life and their world (Rothacker 1934, 38). Philosophy had thus to provide insight into the "life laws of Völker" (Lebensgesetze der Völker; 5). Rothacker defined Völker as the "bearers and creators" of all "moral, cultural, and spiritual life" (38). Völker were characterized by both biological and cultural aspects. Rothacker held that Völker rested on biological groups: families, clans, and tribes were their biological sources which ensured the future of a community. The members of a community also shared a way of life and possessed common spiritual goods. A community established a specific attitude by its struggle with the natural and social environment (38).

Rothacker held that cultures were rooted in shared ways of life. Cultures emerged, when the specific attitude of a community was completed in a "characteristic form" (durchgeprägte Form) that shaped all areas of life. Rothacker defined the 
"characteristic form" of Kulturvölker (cultural people) as particular, collective, public, homogeneous, comprehensive, and productive (73-79; 1948, 68 f.).

Rothacker's particularist understanding of cultures obviously had a relativistic tendency. It was based on the conviction that there was no neutral response to the challenges of life. Rothacker referred to the pragmatic principle of active selection that grounded the "positive relativism" of his middle period. Immersed in a concrete situation, humans could only develop perspectival knowledge and partial solutions. Their knowledge and their activities were guided by their practical interests and specific desires. The partiality of knowledge and actions impacted the character of the emerging attitudes: these basic orientations in life possessed a weltanschaulich character. Rothacker assumed that our beliefs are dependent on the contexts we lived in. Moreover, the different ideological orientations of human life give rise to plurality of "won worlds" (erkämpfte Welten; 99 f.). Rothacker held that each culture created a particular world.

Contrary to his middle work, the mature Rothacker explicitly rejected the label relativism for his perspectivist view. He illustrated the non-relativistic feature of his mature perspectivism by a simple example: What a farmer spontaneously interprets as "wood", the forester takes as a forest, the hunter as a hunting ground, and the fugitive as a hiding place (Rothacker 1934, 85 f.; see also 1948, 161,170 f.). Rothacker argued that these divergent perspectives reveal different aspects of the same reality and do not contradict each other (Rothacker 1934, 86; $1948,173,177)$.

Rothacker used the realist core of his mature perspectivism to rank communities. He assumed that some human groups developed better responses to the practical challenges of life. Cultures were thus an achievement of communities. Human history was shaped by the cultural existence of certain Völker who constituted the peak of human excellence. Only these communities possessed historical significance. All other human groups were forgotten-and justifiably so (see, e.g., Rothacker 1934, 53). This view shows us the main reason for the rejection of 
relativism by Nazi philosophers: They were convinced that there was a hierarchy of Völker and believed in an objective justification of their ranking.

\section{Conclusion}

This chapter started with a critical examination of the widespread reproach that relativism and NS are connected historically as well as systematically. My investigation of the historical context revealed a rather different picture: Nazi intellectuals presented NS as the overcoming of the problem of relativism. The prevalence of anti-relativist motifs in Nazi debates is especially significant because a similar kind of fascism committed to relativism at that time.

The anti-relativistic tendency of Nazi thought was confirmed by the views of two major philosophers who associated their philosophy with NS. Bauch welcomed NS with a lecture that included a fierce polemic against relativism. His polemics also demonstrated that modern anti-relativism could rely on popular motifs from the philosophical tradition. Anti-relativist sentiments were thus a strong motivating factor for the philosophical collaboration with NS.

The development of Rothacker's philosophy was characterized by significant changes. Rothacker committed to the "positive relativism" of historicism during the 1920s. The revision of his philosophical views was, however, accompanied by a political turn to NS and a withdrawal from relativism in the $1930 \mathrm{~s}$.

Both cases showed that Nazi philosophers had to reconcile the relativistic tendency of their völkisch particularism with the anti-relativistic assumptions of their views. They believed in the superiority of certain Völker and races. Bauch argued that nationalism belonged to the transcendent realm of objective values. Rothacker insisted on the realist foundation of his perspectivism.

My chapter also demonstrates the pejorative meaning of term relativism in the context of NS. Nazi intellectuals and Nazi critics shared a specific understanding of 
relativism: They all considered relativism as a fundamental problem that had to be overcome. Relativism often covered alleged intellectual "ills" such as subjectivism, historicism, skepticism, materialism, or nihilism. Moreover, "relativism" was mostly used in a polemical sense: relativists were always the others, the philosophical and/or political enemies. To label someone a relativist was almost tantamount to making him an enemy.

\section{Acknowledgement}

This work was supported by the European Research Council (ERC) under Grant 339382.

For critical comments and helpful suggestions, I am indebted to audiences in Vienna as well as to the editor.

\section{Literature}

Apel, K.-O. (1988), "Zurück zur Normalität? Oder könnten wir aus der nationalen Katastrophe etwas Besonderes gelernt haben? Das Problem des (weltIgeschichtlichen Übergangs zur postkonventionellen in spezifisch deutscher Sicht," in Kuhlmann (1988), 91-142.

Baeumler, A. (1943), Alfred Rosenberg und der Mythos des 20. Jahrhunderts, München: Hoheneichen.

Bauch, B. (1917), “Vom Begriff der Nation. Ein Kapitel zur Geschichtsphilosophie," Kant-Studien 21: 139-162.

-(1934/35), "Wert und Zweck," Blätter für Deutsche Philosophie VIII: 39-59.

-(1935), Grundzüge der Ethik, Stuttgart: Kohlhammer

Böhler, D. (1988), “Die deutsche Zerstörung des politisch-ethischen Universalismus. Über die Gefahr des - heute (post-) modernen - Relativismus und Dezisionismus," in Kuhlmann (1988), 166-216. 
Böhnigk, V. (2002), Kulturanthropologie als Rassenlehre: nationalsozialistische Kulturphilosophie aus der Sicht des Philosophen Erich Rothacker, Würzburg: Königshausen und Neumann.

Danneberg, L. (2013), Wissenschaftsbegriff und epistemischer Relativismus im Nationalsozialismus, url: http://fheh.org/wpcontent/uploads/2016/07/relativismusld.pdf (18/03/16).

Del Negro, W. (1942), Die Philosophie der Gegenwart in Deutschland, Leipzig: Felix Meiner.

De Vries, J. (1935a), "Wissenschaft, Weltanschauung, Wahrheit," Stimmen der Zeit 129: 93-105.

-1935b, "Rationale oder irrationale Weltanschauung," Stimmen der Zeit 129: 380-392.

Dilthey, W. (1898), "Die Kultur der Gegenwart und die Philosophie," in Gesammelte Schriften, vol VIII, 3rd ed., Göttingen: Vandenhoeck \& Ruprecht, $1962,190-205$.

Felken, D. (2006), “Nachwort”, in Spengler (2006), 1250-1270.

Fischer, J. (2008), Philosophische Anthropologie. Eine Denkrichtung des 20. Jahrhunderts, Freiburg: Karl Alber.

Gross, R. (2016), "The 'True Enemy:' Antisemitism in Carl Schmitt's Life and Work", in The Oxford Handbook of Carl Schmitt, edited by Jens Meierhenrich and Oliver Simons, Oxford: Oxford University Press, 96-116.

Herbert, C. (2001), Victorian Relativity: Radical Thought and Scientific Discovery, Chicago: University of Chicago Press. 
Kellerwessel, W. (2014), "Universalism and Moral Relativism: On Some Aspects of the Modern Debate on Ethics and Nazism," in Nazi Ideology and Ethics, edited by W. Bialas and L. Fritze, Newcastle: Cambridge Scholars, 367-387.

Kelsen, H. (1920), Vom Wesen und Wert der Demokratie, Tübingen: Mohr. -(1948), "Absolutism and Relativism in Philosophy and Politics", The American Political Science Review 42, 906-914.

Köhnke, K.-Ch. (1996), Der junge Simmel in Theoriebeziehungen und sozialen Bewegungen, Frankfurt a. M.: Suhrkamp.

Krieck, E. (1936), Nationalpolitische Erziehung (1932), 20th ed., Leipzig: ArmanenVerlag.

-(1938), Völkisch-politische Anthropologie, vol. 3, Leipzig: Armanen-Verlag.

Kuhlmann, W. (ed.) (1988), Zerstörung des moralischen Selbstbewußtseins: Chance oder Gefährdung? Frankfurt a. M.: Suhrkamp.

Kinzel, K. (2019), "The History of Philosophy and the Puzzles of Life: Windelband and Dilthey on the Ahistorical Core of Philosophical Thinking," in Kusch et al (2019), 26-42.

Kusch, M. (1995), Psychologism, London and New York: Routledge.

-(2019), "Simmel and Mannheim on the Sociology of Philosophy of Philosophy, Historicism and Relativism", 165-180.

Kusch, M., Kinzel, K., Steizinger, J., Wildschut, N. (2019), The Emergence of Relativism: German Thought from the Enlightenment to National Socialism, London and New York: Routledge. 
Lieber, H.-J. (1966), “Die deutsche Lebensphilosophie und ihre Folgen,” in Freie Universität Berlin (ed.), Nationalsozialismus und die deutsche Universität, Berlin:

De Gruyter, 92-108.

Lukàcs, G. (1954), Die Zerstörung der Vernunft. Der Weg des Irrationalismus von Schelling zu Hitler, Berlin: Aufbau.

Meyers Lexikon (1942), vol. 9, 8th ed., Leipzig: Bibliographisches Institut.

Mussolini, B. (1921), “Nel solco delle grandi filosofie: relativismo e fascism," II Popolo d'Italia, November 22.

Raphael, L. (2014), “Pluralities of National Socialist Ideology. New Perspectives on the Production and Diffusion of National Socialist Weltanschauung," in Visions of Community in Nazi Germany. Social Engineering and Private Lives, edited by M. Steber and B. Gotto, Oxford: Oxford University Press, 73-86.

Rosenberg, A. (1938), Der Mythus des 20. Jahrhunderts (1930), $125^{\text {th }}-128^{\text {th }}$ ed., München: Hoheneichen.

Rothacker, E. (1912), Über die Möglichkeit und den Ertrag einer genetischen Geschichtsschreibung im Sinne Karl Lamprechts, Leipzig: R. Voigtländer. -(1926), Logik und Systematik der Geisteswissenschaften, in Handbuch der Philosophie, Section II, Contribution C, edited by A. Baeumler and M. Schröter, München und Berlin: Oldenbourg.

-(1934), Geschichtsphilosophie, in Handbuch der Philosophie, Section IV, Contribution F, , München und Berlin: Oldenbourg. -(1948), Probleme der Kulturanthropologie, Bonn: H. Bouvier u. Co.

Sandkühler, H. J. (2009), Philosophie im Nationalsozialismus, Hamburg: Felix Meiner. 
Schmitt, C. (1916), Theodor Däublers "Nordlicht:" Drei Studien über die Elemente, den Geist und die Aktualität des Werkes, München: G. Müller -(1931), "Übersicht über die verschiedenen Bedeutungen und Funktionen des Begriffs der innerpolitischen Neutralität des Staates," in Der Begriff des Politischen, Berlin: Duncker \& Humblot, 2002, 97-101. (2009), Politische Theologie. Vier Kapitel zur Lehre von der Souveränität (1922), Berlin: Duncker \& Humblot.

Sieg, U. (2013), Geist und Gewalt. Deutsche Philosophen zwischen Kaiserreich und Nationalsozialismus, München: Carl Hanser.

Sluga, H. (2013), Heidegger's Crisis: Philosophy and Politics in Nazi Germany, Cambridge, Mass.: Harvard University Press.

Spengler, O. (2006), Der Untergang des Abendlandes (1922), München: Deutscher Taschenbuch Verlag.

Steizinger, J. (2015), "In Defense of Epistemic Relativism: The Concept of Truth in Georg Simmel's Philosophy of Money," Proceedings of the 38th International Wittgenstein-Symposium XXIII, 300-302.

-(2016), "Politik versus Moral. Alfred Baeumlers Versuch einer philosophischen Interpretation des Nationalsozialismus," Jahrbuch zur Geschichte und Wirkung des Holocaust, vol 20, 29-48.

-(2017a), "Reorientations of Philosophy in the Age of History: Nietzsche's Gesture of Radical Break and Dilthey's Traditionalism," Studia philosophica 76: $223-244$.

-(2017b), “Vorbild, Beispiel und Ideal. Zur Bedeutung Goethes in Wilhelm Diltheys Philosophie des Lebens," in Goethe um 1900, edited by C. Haas, J. Steizinger, and D. Weidner, Berlin: Kulturverlag Kadmos, 27-49. -(2018), "The Significance of Dehumanization: Nazi Ideology and its Psychological Consequences," Politics, Religion \& Ideology 19: 139-157. 
-(2019), "National Socialism and the Problem of Relativism," in Kusch et al (2019), 233-251.

Stöwer, R. (2012), Erich Rothacker: Sein Leben und seine Wissenschaft vom Menschen, V\&R University Press: Göttingen.

Tugendhat, E. (2009), “Der moralische Universalismus in Konfrontation mit der Nazi-Ideologie," Jahrbuch zur Geschichte und Wirkung des Holocaust 13: 61-75.

Windelband, W. (1884), "Kritische oder Genetische Methode," in Präludien. Aufsätze und Reden zur Philosophie und ihrer Geschichte, vol. 2, Tübingen: Mohr, $1915^{5}, 99-135$.

Wolin, R. (2004), The Seduction of Unreason: The Intellectual Romance with Fascism from Nietzsche to Postmodernism. Princeton: Princeton University Press.

Wolters, G. (1999), “Der 'Führer' und seine Denker. Zur Philosophie des 'Dritten Reichs,'" Deutsche Zeitschrift für Philosophie 47: 223-251.

'All translations are my translations.

ii For careful examinations of this historical context see Steizinger 2017a, Kusch et al 2019, Kinzel this volume.

iii For examples see Sluga 1993, Wolters 1999, Sandkühler 2009, Sieg 2013. The research on philosophy during National Socialism is focused on Martin Heidegger. His case is, however, not exceptional from a historical point of view.

iv Note that Benito Mussolini (1883-1945) characterized fascism as a relativistic movement because of its anti-scientism and voluntarism. With his belief in the ultimate authority of pure power, the fascist despised all fixed and stable categories (Mussolini 1921).

v On Dilthey's theory of worldviews see Steizinger 2016; 2017a, b; Kinzel 2019.

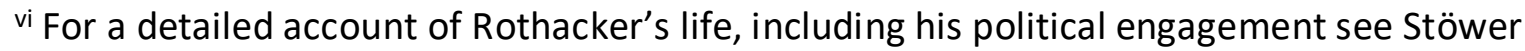
2012. 
vii See, e.g. Krieck 1936: 3, 7 f.; 1938, 11; Rosenberg 1938, 694 f.; Del Negro 1942, 10-13; Baeumler 1943, 27 f., $67 \mathrm{ff}$.

viii See, e.g., Del Negro 1942, 11 f., 42 f. For careful accounts of Simmel's relativism see Steizinger 2015, Kusch 2019.

ix For a detailed account of the prize question of 1936 see Steizinger 2019.

${ }^{x}$ For detailed accounts of this strand of Nazi ideology see Steizinger 2016b, 2018, 2019.

${ }^{x i}$ Kelsen indeed considered the relativistic denial of absolute truth and values as the prerequisite of liberal democracy. He believed that philosophical absolutism goes hand in hand with political absolutism and is thus the philosophical henchman of despots, dictators, and autocrats (Kelsen 1920; 1948).

xii See Deutsche Philosophische Gesellschaft 1918/19. This statement can be found on the back cover of the first issue of the Beiträge zur Philosophie des deutschen Idealismus (Contributions to the Philosophy of German Idealism), the journal of the DPG (latter renamed to Blätter für Deutsche Philosophie [Pages for German Philosophy). For detailed accounts of the DPG see Sluga 1995, Sieg 2013.

xiii Bauch included his lecture as a chapter in his Grundzüge der Ethik (Fundamentals of Ethics. See Bauch 1935, 287-310.

xiv For more details about the DPG conference see Sluga 1993, 154-164.

xv The contrast between "Jewish" egoism and German selflessness was a key motif of Nazi antisemitism (see Steizinger 2018, 147 f.).

xvi The literature on Rothacker's association with NS is problematic because most authors identify Nazi ideology with biological racism. Böhnigk (2002) believes that he can convict Rothacker's cultural anthropology of a commitment to biological racism. Yet Rothacker was obviously no biological racist, although he discussed the concept of race and clarified its role within his cultural anthropology (Rothacker 1934, 132-145). Rothacker's dismissal of biologist concepts of humanity is not tantamount to distancing himself from NS. His intellectual connection with NS should thus be not ignored, like Fischer (2008) does. Stöwer's (2012) biography gives a detailed account of Rothacker's political association with NS. Yet Stöwer (2012, $350 \mathrm{f}$.) explains this engagement by the social prejudices and cultural stereotypes Rothacker held. He does not see that Rothacker's cultural anthropology developed a völkisch particularism that corresponded with an important strand of Nazi ideology. 